\title{
Choice of Performance Measures and Performance of Textile Sector in Bangladesh
}

\author{
Mohammad Mobarak Hossain ${ }^{*}$, Tahsina Tabassum ${ }^{2}$ \\ ${ }^{1}$ Lecturer, Department of Textile Engineering, Bangladesh University of Business and Technology (BUBT), Dhaka, BANGLADESH \\ ${ }^{2}$ Assistant Professor, Department of Management, Bangladesh University of Business and Technology, Dhaka, BANGLADESH \\ "E-mail for correspondence: mobaraknits89@gmail.com
}

https://doi.org/10.18034/abr.v9i2.271

\begin{abstract}
This study seeks out to establish the influence of quality as well as performance-based manufacturing strategy, diverse in performance measures, firm's size, their interrelationship, and joint effects with the subjective measures on textile firm's performance. Financial, objective, subjective, and nonfinancial measures have been taken into consideration. Bangladesh needs competitive strategies and measures to meet the challenges \& opportunities for creating a sustainable position in the global market. Performance measures have been taken by the textile industries of Bangladesh to improve the performance. The influence of those measures is not always improving the performance as found in the earlier study. Responses from mid-level managers of 30 textile industries in Bangladesh have been taken into consideration using survey method using descriptive statistics, factor analysis, regression and correlation analysis. The result shows extensive use of measures and only subjective measures do not increase the performance of the industry, but customer-oriented measures, sustainability measures, manufacturing quality strategy with firm size increase the performance of the textile sectors. The study will open the scope of further exploration in the performance of the textile sector of Bangladesh.
\end{abstract}

JEL Classification Code: G 21

Key words: Measures, performance, choices, sustainability

\section{INTRODUCTION}

RMG's with the help of the other textile industries linked back with it has already experienced over $100 \%$ growth rate from 1983-2000 and again reduced to $2.63 \%$ during 2000-2010 and again started recovering to $8.76 \%$ during the last few years (BGMEA, n.d.). RMG sectors contribute $83.49 \%$ of the total export earning with 4.0 million of workers. In Asia, Bangladesh holds the second position after China in exporting clothing by providing $45 \%$ of industrial employment and contributing $6 \%$ of national income. The contribution of this sector makes up $80 \%$ of the export earnings and 23\% of the country's domestic product (GDP) (Masum \& Inaba, 2015). Since 1978 cheap workforce is the key criteria for the growth in this sector. Bangladesh is trying to develop her performance comparing with India, Pakistan, China, and Thailand that are at the higher stage of development (Habib, 2009; Chowdhury, 2011). Response to 'globalization'; 'competitive markets'; 'economies of scale' and 'specialization of labor and management'; the organization may take its own agendas and performance criteria. But the size of the firms and measurements criteria that practiced in the firm is also different (Islam, 2015). These steps sometimes may be contradictory to the organizational strategic objectives (Starcher, 1992; Scholtes, 1993; Harper, 1984; Kaplan and Atkinson, 1989). In the textile industry, tragedies occur more frequently to hinder both the performance in an ethical way, and the continuous improvement lose the trends. So, a perfect blend of quality strategy response with performance measures is mandatory. It is also noted that quality strategy, factors of technological advancement, the working environment must also come up with the global challenges (Hasan et. al., 2016). Earlier, firms traditionally practice financial measures for improving performance. With the new competitive situation, financial measures are mandatory but, associated with non-financial 
measures (Ittner and Larcker, 1995). It is also distinguished that sustainability term that previously not taken into consideration, in the present scenario it being a compulsory issue. The record shows that manufacturing firms, using lean techniques, have global as well as local benchmarking regarding continuous development (Farhana and Amir, 2009). Lean manufacturing techniques are now becoming key performance factors for the industry to work more efficiently. The performance sometimes faces obligations imposed by the name of compliance that catalyst the competition internally and externally in the market (Hasan, 2013). Recently, 'economic'; 'social'; 'environmental issues' (energy efficiency, conservation, and consumption measures) are taken by many industries to make the sustainability of their performance (Haque, 2015). Many try to adopt informal incentives, employee training to positively drive the performance considering operational risk (Shafiqul, 2014); Noor-E-Hasnin and Ahsan, 2016). Quality strategy, diverse in performance measures, and sustainable measures are now mandatory issues for increasing the firm's performance. This study has taken an endeavor to show the influence of quality strategy, financial, nonfinancial objective, and subjective and sustainability issues on the performance of the textile industry.

The significance of the study: To contribute in the economic growth of Bangladesh, the understanding of the measures for performance, strategies for achieving goals set by the firms and making it sustainable has become the most vital part for the future of the textile industry in Bangladesh. So, the significance of the study lies in exploring the strengths of a quality strategy set by the upper authority, identifying the determinants of financial performance measurements, investigating the potentiality of objective and subjective non-financial measures, firm's sustainability measures and their influence on performance. To stay competitive in present scenario quality strategy-measurement, diversified performance measures, sustainability measures should be linked up for increasing performance.

\section{Objective of the Study}

The main objectives to conduct this study are to show the influence of measurement diversity on firm's performance; identify the influence of size on firm's performance; recognize the influence of quality strategy and measurement fit on a firm's performance, and find the effect of subjective non-financial measures on a firm's performance.

\section{LITERATURE REVIEWS}

A literature review is a framework for providing a solid background to the subject matter based on past research work. As the comprehensive study and interpretation, this helps to address a specific topic (Aveyard, 2010).
Quality Strategy: Quality may define as the acceptance of goods or service. A strategy is the adoption or choosing courses of action or set of activities or stream of decisions by the allocation of resources for the long-run goals and objectives of an enterprise to bring a exclusive combination of value (Chandler, 1962; Porter, 1966; Mintzberg, 2007). The term 'Made in Bangladesh' is a sign of quality and pride for workers and consumers in the textile clothing sector (Baumann-Pauly et al., 2015). This expanding sector of Bangladesh still in need to set qualityrelated strategy to update their superiority and efficiency in production. A perfect blend of operational and tactical strategy will interrelate plan, ploy, pattern, position and perspective that cope up with excellence and undoubtedly no effect on firm's performance (Mintzberg, 1987; Moseley, 2009). Highly rational managers are the crucial element for the perfectness of these measures by an alignment between strategy and performance measures (Chandler, 1977). Top industries agreed-upon measures that the manager understands. They also balance those by linking and updating both strategy and trials by communicating among the employee (Lingle and Schiemann, 1996). So, the combination of 'quality strategy -measurement fit' aligned with different performance measurements reflecting the performance should be considered.

Financial Performance Measures: For private and local sectors, performance measurement is a legislative requirement. Internal and external factors determine the measures of performance in terms of the financial and non-financial perspectives. Actions related to the financial perspective should incorporate elements of both risks and return to define performance expected from the strategy. These measures vary largely focusing on manufacturing and step by step, emphasizing all business activities that ultimately results in customer-oriented satisfaction (Zairi and Letza, 1994). For financial measures, organizations willingly asked for audit instead of multiple inspections and drew the trust of the customer in business (Neely, 1999). These processes make the organization competitive and capable in a continually changing and dynamic environment. But besides audit inspection, close monitoring and update strategy is also needed as well (Taticchi et. al., 2008). Financial performance is associated with competitiveness and result orientation. So, a company must use relevant financial performance measures for achieving sustainability in success (RSA, 1994).

Objective Non-Financial and Subjective Measures: Relevant literature shows that a manager can understand the critical factors for long term success with the use of non-financial measures for performance. Without this firm cannot gain sustainability in competitive markets. Customer-oriented performance measures, internal business operation, employee-oriented measures, innovation, and learning are included in these measures 
(Chow and Van der Stede, 2006). The competitive strength of the labor-intensive firm depends on the skills and knowledge of employees (Absar et. al., 2010). Innovation and learning perspectives are also associated with the encouragement of investment for future growth to ensure continuous improvement with the change of needsperceptions and expectations such as human resources. Thus goals and goals-oriented-measures are also developed aligned with strategy (Manas, 1999; Kaplan and Norton, 1992). In customer-oriented measurement, customer satisfaction is the result of retained or repeat customer that is new buyers. Internal Business Perspective includes internal critical activities related to production, minimizing costs, and maximizing quality for improving efficiency in regards to the company's success.

Management should consider all the factors that balance between measurements and performance and integrate those factors to take further decisions (Lynch and Cross, 1991; Kaplan and Norton, 1992). For surviving in continuous improvement redesign based on holistically consideration of horizontal flows of information and materials are essential (Hammer and Champy, 1993; Slack et. al., 1995). This information and material ultimately come from customer, employee, and internal business perspective. Subjective measures are the tools that reflect one's perception of the organization. Individual measures are the criteria that uphold evaluating ones toward the decision making in the organization.

Sustainability Measures: According to IISD sustainable development means-"Adopting business strategies and activities that meet the needs of the enterprise and its stakeholders today while protecting, sustaining and enhancing the human and natural resources that will be needed in the future" (IISD, 1992). To design a competitively sustainable business model, requires creativity, insight, a good deal of customer, competitor, supplier information, intelligence, and the strategy is the prerequisite for implementing it. But to rationalize, and articulate significant tacit component in business experimentation, learning is required (Teece, 2010). On the other hand determinants of competitive success are also measured with the quality of service, flexibility, resource utilization and innovation (Fitzgerald et. al., 1992). Sustainability measures include economic, social, and environmental issues consideration while dealing with improving performance.

Competitive and corporate strategies have evolved substantially in the past to analyze the environment, firms' position, develop strategic advantages and understanding threats from competitors (CasadesusMasanell and Ricart, 2010). For sustainability of Bangladesh textile industries challenges, opportunities, and threats are now more significant for the sustainability in the global market (Mostafa, 2006). The present study has taken sustainability measures as one of the measurement techniques of the textile industry for the growth of RMG sectors in Bangladesh.

Performance: The previous study found that firms using more extensive performance measurement systems have higher performance but partial supports to alignment or fit between the strategy-performance measures pairing with performance. The quality-based-strategy has a less direct effect on performance. But more extensive use of non-financial measures having similar or less qualitybased-strategy enjoying the higher performance (Ittner, and Larcker, 1995; Chow and Van der Stede, 2006). Hence, to find out the determinants for performance measurement with the strategy set to attain the goals set by the industry, interrelation of performance measures and the performance are the main objective of this study as well as with subjectivity and sustainability.

\section{Research Methodology}

Research Design: This study is quantitative research in nature. To approach the quantitative learning the study has adopted a descriptive research design and considers survey methods to meet the respondents.

Respondents of the samples: Considering the central role in implementing the strategy, setting performance measurements tools, and evaluating performance, the study target mid-level managers of the firm who usually holds the position for responding survey.

Questionnaire design and sample collection: The questionnaire is developed in 'Google form' to collect the response from the target groups. Due to practical circumstances in this country, the replies are ensured by requesting through emails and personal contacts so that the respondents give their answers in a convenient time being. The study restricts the target samples to 100 firms through questionnaire mailing and personal interactions. But it received only 39 responses, 09 of which is unusable for a range of reasons, leaving a sample of 30. Among them, 26.6\% RMG industries, $10 \%$ doing individual business through yarn and fabric (woven and knit) manufacturing, and dyeing process; and rest $63.33 \%$ is composite textile industries. $100 \%$ male respondents with, having 53\% experienced between 5-10 years in this field. Here, RMG industries are trying to follow the lean manufacturing system in their industry, and others are facing challenges with adopting this method to meet the global challenges. Thanks to honorable respondents from various industries in this textile sector namely- Young One, Union Group of Company, Mohasin Knitwear, Hamim Group, SGS group, Fakir Apparels Ltd., Senma Clothing China, Knit Concern Group, Jamuna Denims Ltd., Asir Knitwear Ltd., Intimate Apparels Ltd., Base Textile Mills Ltd., Regent Textile Mills Ltd., Textiles, Apparel Division-Beximco, Noman Weaving Mills Ltd., Impress-Newtex Composite Textiles Ltd., Regency Garments Ltd., ABA Group, Asrotex Group, Cotton Zone 
Ltd., GMS Composite Knitting Ind. Ltd. and so on to make this work a valuable resources for the further development in the performance measures.

Variables used: The study classified variables into two categories as dependent and independent. Here financial measures, objective non-financial measures, subjective non-financial measures, quality strategy, sustainability measures stand as independent variables, and firms performance stands for the dependent variable.

Sources of data: Both the primary and secondary data are used in this study. Secondary data and information are collected from the existing literature and different published reports in the said field, and the primary data are collected through a comprehensive questionnaire survey.

Measurement scales: A structured close-ended questionnaire with an open-ended questionnaire used for collecting primary data. Three different parts consists structured closed-ended questionnaire with a five-point scale Likert scale. In this part questionnaire regarding quality strategy was structured with $5=$ a large extent, $4=a$ moderate extent, $3=$ some extent, $2=$ a small extent, $1=$ not at all. Performance related questions are structured by $5=$ well above average, $4=$ above average, $3=$ average, 2 =below average, $1=$ well below average. Another contains both closed and open-ended regarding financial measures, objective non-financial measures, subjective non-financial measures, and sustainability measures. In the closed-ended section, respondents are asked to check $(\sqrt{ })$ the item among the entire relevant element which is applicable in their respective firm. It follows multiple response questionnaires, and in the open-ended section, respondents were asked to add their comments.

Table 1: Questionnaire content references

\begin{tabular}{|l|l|}
\hline $\begin{array}{l}\text { Different } \\
\text { performance } \\
\text { measurements } \\
\text { tools }\end{array}$ & References \\
\hline $\begin{array}{l}\text { Financial } \\
\text { Performance }\end{array}$ & Van der Stede et al., 2006, \\
Measures & Chow and Van der Stede, \\
Objective Non- & Ne06), \\
financial measures & Bennett and James, 1999, \\
Subjective non- \\
financial measures \\
$\begin{array}{l}\text { Quality strategy } \\
\text { Sustainability }\end{array}$ & James, 1997, \\
measures & Fiksel, 1997, et al., 1999 and \\
\hline
\end{tabular}

Tools and techniques used: Descriptive statistics, Factor analysis, Regression, and Correlation analysis technique has been used to identify the influence of the different performance measurements on a firm's performance. Statistical Package for Social Science (SPSS version 23) software has been used to calculate the above statistics and interpret the results.

Size of the firm determination: The study determines the size of the firm by considering the number of employees. The study categorizes these considering 0 as small size and 1 for large size industry having lower and higher than the average values respectively.

Framework for regression analysis: This study aimed to fit the regression model: $\mathrm{Y}=\mathrm{a}+\mathrm{bX}$; wherein it assumes $\mathrm{Y}$, as the dependent variable: Firm's Performance, and $X$ is the independent variable (Different performance measures).

\section{Hypothesis:}

$\mathrm{H}_{1}$ : There is a significant influence on diversified performance measures on performance of the industry;

$\mathrm{H}_{2}$ : There is a significant influence of size of industry on its performance;

$\mathrm{H}_{3}$ : There is a significant impact of quality strategy and measurement fit on performance of the industry;

$\mathrm{H}_{4}$ : There is a significant influence of subjective measures on performance of the industry.

\section{RESULTS AND ANALYSIS}

\section{Performance Measures}

Performance measurement section comprises financial measures, one subsection on objective non-financial measures (customer-oriented measures, internal operating measures, employee-innovation measures, employee-learning measures, and sustainability measures), and one subsection on subjective performance measures. Table 1 reports the distributional statistics obtained from the respondents from different textile industries.

Responses from 14 among 30 took an effort to write in a total 30 of additional measures that are added to the subjective measures to increase the strength of the observation skill that they are practicing in their industry.

Table 2 shows that among the sample industries, the average performance measurement system contains 8 percent financial measures, 92 percent non-financial measures, and 42 percent subjective measures in which they suggested 5 percent key performance indicators of their industry.

For operating the number of the measures from different subsections, categorical diversity (catdiv.) is measured considering 1 for checking each of financial-measures, non-financial measures, sustainability-measures, and subjective-measures (Chow and Van der Stede, 2006). 
Table 2: Performance measures compositions $(n=30)$

\begin{tabular}{|l|c|c|c|c|}
\hline & Min & Max & Mean & Standard deviation \\
\hline Number of financial measures (\#fin) & 0 & 8 & 2 & 3 \\
\hline Number of objective non-financial measures(\#nonfin) & 2 & 45 & 25 & 14 \\
\hline Number of customer-oriented measures(\#cus) & 0 & 9 & 3 & 3 \\
\hline Number of internal operating measures(\#ino) & 0 & 11 & 4 & 3 \\
\hline Number of employee innovation measures (\#ein) & 0 & 8 & 2 & 2 \\
\hline Number of employee learning measures (\#elearn) & 0 & 7 & 3 & 2 \\
\hline Number of sustainability measures(\#sus) & 0 & 5 & 1 & 2 \\
\hline Number of subjectivity measures(\#sub) & 0 & 26 & 10 & 7 \\
\hline Number of key performance indicators(\#kpis) & 0 & 5 & 1 & 2 \\
\hline Total number of measures(\#total) & 2 & 51 & 27 & $\mathbf{1 6}$ \\
\hline Percent of financial measures (\#fin) & 0.00 & 0.29 & 0.08 & 0.07 \\
\hline Percent of objective non-financial measures(\#nonfin) & 0.71 & 1.00 & 0.92 & 0.07 \\
\hline Percent of customer-oriented measures(\#cus) & 0.00 & 0.33 & 0.11 & 0.09 \\
\hline Percent of internal operating measures(\#ino) & 0.00 & 0.54 & 0.15 & 0.14 \\
\hline Percent of employee innovation measures (\#ein) & 0.00 & 0.20 & 0.06 & 0.06 \\
\hline Percent of employee learning measures (\#elearn) & 0.00 & 0.30 & 0.08 & 0.07 \\
\hline Percent of sustainability measures(\#sus) & 0.00 & 0.17 & 0.04 & 0.05 \\
\hline Percent of subjectivity measures(\#sub) & 0.00 & 1.00 & 0.42 & 0.24 \\
\hline Percent of key performance indicators(\#kpis) & 0.00 & 0.50 & 0.05 & 0.10 \\
\hline Categorical measures for measurement diversity(\#catdiv) & 1.0 & 4.0 & 2.7 & \\
\hline
\end{tabular}

\section{Manufacturing Strategy}

Quality-based manufacturing strategy measured from primarily according to the following question. This part includes 11 items which empirically load on one factor
(Table 2). Q Strat, a composite variable, is measured by the average value of the industrial emphasize on quality measures for their performance where, $\mu 3.82, \sigma 0.59$, Cronbach $\alpha$ 0.806, and Eigenvalue 3.875.

Table 3: Measures of Quality Strategy and Performance $(n=30)$

Quality Strategy measurement ${ }^{1}$ :

\begin{tabular}{|c|c|c|c|}
\hline \multicolumn{2}{|r|}{$\mu 3.82, \sigma 0.59$, Cronbach $\alpha 0.806$ and Eigenvalue 3.875} & Factor loading & Alpha if item deleted \\
\hline 1. & Are non-management employees evaluated for quality performance? & .599 & .789 \\
\hline 2. & $\begin{array}{l}\text { Do non-management employees participate in quality improvement } \\
\text { decisions? }\end{array}$ & .719 & .774 \\
\hline 3. & $\begin{array}{l}\text { Is building awareness about quality among non-management } \\
\text { employees ongoing? }\end{array}$ & .568 & .791 \\
\hline 4. & $\begin{array}{l}\text { Are quality performance data displayed at employee } \\
\text { workstations/areas? }\end{array}$ & .369 & .807 \\
\hline 5. & $\begin{array}{l}\text { Are suggestion programs for quality improvement among non- } \\
\text { management employees used? }\end{array}$ & .534 & .798 \\
\hline 6. & $\begin{array}{l}\text { Are programs in place to improve cycle-times (e.g., by reducing time- } \\
\text { delays or non-value-added activities in manufacturing)? }\end{array}$ & .566 & .790 \\
\hline 7. & Are coordination of quality improvements within the organization? & .453 & .799 \\
\hline 8. & Are key performance indicators (KPIs) measure business performance? & .714 & .775 \\
\hline 9. & $\begin{array}{l}\text { Do strengths, weaknesses, opportunities, and threats (SWOT) evaluate } \\
\text { performance? }\end{array}$ & 661 & .788 \\
\hline 10. & $\begin{array}{l}\text { Do political, economic, social, technological, legal, and environmental } \\
\text { (PESTLE) influence performance? }\end{array}$ & .777 & .770 \\
\hline 11. & Does management follow lean manufacturing techniques? & .423 & .807 \\
\hline
\end{tabular}

${ }^{1}$ Anchored as (1) not at all, (2) low extent, (3) medium extent, (4) high extent, and (5) very high extent. 
Performance $^{2}$ :

\begin{tabular}{|c|c|c|c|}
\hline \multicolumn{2}{|r|}{$\begin{array}{l}\text { Relative to the industry average } \\
\mu 3.93, \sigma 0.60, \text { Cronbach } \alpha 0.813 \text { and Eigenvalue } 3.553\end{array}$} & Factor loading & Alpha if item deleted \\
\hline 1. & Financial performance of your department & .573 & .802 \\
\hline 2. & Customer-oriented performance of your department & .413 & .821 \\
\hline 3. & The internal operating performance of your department & .476 & .807 \\
\hline 4. & Employee-oriented Innovation performance of your department & .767 & .778 \\
\hline 5. & Employee-oriented Learning performance of your department & .687 & .787 \\
\hline 6. & Subjective performance of your department & .774 & .772 \\
\hline 7. & Sustainability performance of your department & .785 & .776 \\
\hline 8. & Key performance indicators performance & .744 & .783 \\
\hline
\end{tabular}

\section{Performance}

Performance of the manufacturing department along the eight dimensions had shown in Table 3; factor analysis holds all items together on one factor with high loadings (Table 3). Performances are measured by arithmetically averaging the individual item scores $\mu$ 3.93, $\sigma$ 0.60, Cronbach $\alpha 0.813$, and Eigenvalue 3.553.

Table 4: Correlation and partial correlation for the performance of the industry $(n=30)$

\begin{tabular}{|c|c|c|c|c|}
\hline & $(1)$ & $\begin{array}{c}(2)^{\mathrm{p}} \\
\text { \#QStrat }\end{array}$ & $\begin{array}{c}(3)^{\mathrm{p}} \\
\text { \#total }\end{array}$ & $\begin{array}{c}(4)^{\mathrm{p}} \\
\text { \#size }\end{array}$ \\
\hline \#QStrat & $.662^{* * *}(30)$ & & & \\
\hline \#Cubs & $-.433^{* * *}(30)$ & & $-.547^{* *}(27)$ & $-.545^{* * *}(27)$ \\
\hline \#Sus & & $0.426^{* *}(27)$ & $0.313^{*}(27)$ & \\
\hline \#nonfin & -.080 & & & \\
\hline \#total & -.078 & & & \\
\hline \#catdiv & .105 & & & \\
\hline \#Size & $.637^{* * *}(30)$ & & & \\
\hline
\end{tabular}

Table 4 shows the correlation (1) and partial correlation coefficients (2-8) of performance concerning different significant variables. Here, the significant positive correlation found with the industries size, emphasize on quality, negatively with customer-oriented measures. But, no relationship with the sustainability measures taken by the industries. In this regard, some partial correlation considering quality, size, and total actions taken separately and in combination. Thus, a significant partial association between the performance of the industry and sustainability-measures while quality and size became control variables combinedly $(\mathrm{p}<0.01$, $\mathrm{df} 26)$ and separately quality $(\mathrm{p}<0.05, \mathrm{df} 27)$ and total measures $(\mathrm{p}<0.10$, df 27).

Table 4 and Table 5 shows that the performance of the firm become higher putting emphasis on quality strategy, customer-oriented measures, sustainability measures, and firm size (adj. $R^{2}$ 0.678). But the performance is not significantly influenced by the non-financial measures, total measures, and categorical diversity of measures taken by the textile industry. Hence, hypothesis $\mathbf{1}\left(\mathbf{H}_{1}\right)$ is rejected $(\mathrm{p}<0.01)$.

Table 5: Regression analysis for performance

\begin{tabular}{|l|c|c|c|c|c|}
\hline & $(1)$ & $(2)$ & $(3)$ & $(4)$ & $(5)$ \\
\hline Constant & $2.113^{* * *}$ & $1.314^{* *}$ & $1.139^{*}$ & $1.150^{* * *}$ & 1.022 \\
\hline \#QStrat & $.393^{* *}$ & $.544^{* * *}$ & $.589^{* * *}$ & $.588^{* * *}$ & $.589^{* * *}$ \\
\hline \#Cus & $-.070^{* *}$ & & & & \\
\hline \#Sus & $.106^{* *}$ & & & & \\
\hline \#Sub & & .01 & & & \\
\hline \#nonfin & & & .005 & & \\
\hline \#total & & & & .005 & \\
\hline \#catdiv & & & & & .093 \\
\hline Size & $.568^{* * *}$ & $.603^{* * *}$ & $.574^{* * *}$ & $.571^{* * *}$ & $.572^{* * *}$ \\
\hline Adj R ${ }^{2}(\mathrm{~F})$ & $\begin{array}{c}0.678 \\
(16.298)\end{array}$ & $\begin{array}{c}0.62 \\
(16.765)\end{array}$ & $\begin{array}{c}0.614 \\
(16.435)\end{array}$ & $\begin{array}{c}0.614 \\
(16.347)\end{array}$ & $\begin{array}{c}0.659 \\
(16.736)\end{array}$ \\
\hline
\end{tabular}

Here, Correlation is significant at the 0.01 level $^{* * *}$, at the 0.05 level $^{* *}$, and at the $0.10^{*}$ level (2-tailed).

On the other hand, the size of the industry significantly influences the performance of the firm table 6, (model 1$5)$. Hence, size considered by measuring a total number of employees has a positive influence on the performance table 5 (model 1-4). So, higher the size of the industry, higher the performance. Hence, hypothesis $2\left(\mathbf{H}_{2}\right)$ is accepted $(\mathrm{p}<0.01)$.

Results show from table 5 and table 6, the performance of the industry is not positively by sustainability measures only. It increases when emphasizing on quality strategy and or firm size is considered as mediating variables (model-1). Here, key performance indicators added to increase the strength of the subjectivity. But the results remain the same. That means, subjective measures have no influence on performance of the industry. Hence; hypothesis $4\left(\mathrm{H}_{4}\right)$ is rejected $(\mathrm{p}<0.01)$.

\section{Quality and measurement diversity}

Table 6 shows the correlation (1) and partial correlation (2$3)$ with respect to different significant variables $(p<0.05)$. Here, the significant correlation found with performance, non-financial measures (customer oriented, internal

\footnotetext{
${ }^{2}$ Anchored as (1) not at all, (2) low extent, (3) medium extent, (4) high extent, and (5) very high extent. 
operating, employee innovation and employee learning measures as well as with the categorical diversity measures $)(p<0.05)$. For the same performance, the industry may less non-financial measures requires more emphasis on quality strategy $(\mathrm{p}<0.05$, df 27$)$. But, by controlling total measures and same size of the fewer customer-oriented measures can positively increase the performance of the industry giving more emphasis on quality strategy $(\mathrm{p}<0.05,26)$.

Table 6: Correlation and partial correlation for quality strategy $(\mathrm{n}=30)$

\begin{tabular}{|c|c|c|c|}
\hline & $\begin{array}{c}(1) \\
(\mathrm{df}=30)\end{array}$ & $\begin{array}{c}(2)^{\mathrm{p}} \\
\text { \#perf }(\mathrm{df}=27)\end{array}$ & $\begin{array}{c}(3)^{\mathrm{p}} \\
\text { \#total }(\mathrm{df}=27)\end{array}$ \\
\hline \#perf & $.662^{* * *}$ & & $.702^{* * *}$ \\
\hline \#fin & & $-.403^{* *}$ & \\
\hline \#cus & $-.611^{* * *}$ & $-.480^{* * *}$ & $-.470^{* * *}$ \\
\hline \#ino & $-.361^{* *}$ & $-.392^{* *}$ & \\
\hline \#ein & $-.485^{* * *}$ & $-.500^{* * *}$ & \\
\hline \#elearn & $-.386^{* *}$ & $-.429^{* *}$ & \\
\hline \#sus & & $-.404^{* *}$ & \\
\hline \#tnonfin & $-.435^{* *}$ & $-.511^{* * *}$ & \\
\hline \#total & $-.442^{* *}$ & & \\
\hline \#catdiv & $-.383^{* *}$ & & \\
\hline
\end{tabular}

From table 5 and 7, Regression models show that to increase the performance as it is highly positively correlated with quality strategy more emphasize are required to the quality strategy considering fewer measures in a customer-oriented, sustainability measures, and non-financial measures (model 1, 4 and 5). Here, number of employees are insignificant for each model. Categorical diversity emphasizing on quality influences performances negatively (model 1-5).

Table 7: Regression for quality strategy emphasize by the industry

\begin{tabular}{|c|c|c|}
\hline & $(1)$ & $(2)$ \\
\hline (Constant) & $1.639^{* *}$ & $1.669^{* * *}$ \\
\hline \#Perf & $.675^{* * *}$ & $.664^{* * *}$ \\
\hline \#tnonfin & $-.016^{* * *}$ & \\
\hline \#Total & & $-.014^{* * *}$ \\
\hline \#Size & -.111 & -.088 \\
\hline Adj R ${ }^{2}$ & .542 & $0.574(12.681)$ \\
$(\mathrm{F})$ & $(12.428)$ & \\
\hline
\end{tabular}

Here, Correlation is significant at the 0.01 level $^{* * *}$, at the 0.05 level**, and at the $0.10^{*}$ level (2-tailed).

From above correlation and regression analysis, quality strategy of the industry is influenced by the customeroriented measures and sustainability measures negatively as well as with the measurement diversity occupied by the firm (model 3). But firm size has no influence significantly on quality strategy taken by the firm (model 1-5). The industry that follows more categorical diversity in measurement requires less emphasis on quality strategy for higher performance (model 3). Here, measures taken by the industry fit with quality strategy will get higher performance.

Quality strategy highly significant for internal operational measures, customer-oriented measures, employee innovation, and learning measures. But, in terms of total measurement diversity, the influence becomes significant while the regression line is calculated for both totalmeasures, and categorical diversity. Here, quality strategy is influenced negatively in both cases (model 2 and 3). On the other hand, customer-oriented measures and sustainability measure alone from non-financial measures influence quality strategy. But, firm's size remains insignificant in all the cases which are same as one of the previous study but, considered here also as a mediating variable (Van der Stede et al., 2006). Hence, hypothesis 3 is accepted $(\mathrm{p}<0.01)$.

\section{Findings of the study in brief}

- Diversity in measures (sustainable, quality strategy, financial, objective, and subjective non-financial measures) have no significant influence on manufacturing quality strategy.

- The industries having large number of employees have higher performance.

- Controlling size and total measures, the customeroriented measures and sustainability measures have a superior impact on the performance of the industry.

- The performance of the industry is increased by applying Quality fit- measurement strategy.

- In this study, subjective non-financial measures have no relationship toward the performance of the industries which result is also similar to one of the previous studies of (Van der Stede et al., 2006).

\section{Limitation and future direction of the study}

The study has accumulated responses from only 30 textile industries of Bangladesh. The study limits the scope and depth of exploration; the sample respondents also do not represent the whole population of the textile sectors. So, the results may be limited to those industries only; not the other. On the other hand, the paper reveals the result depends only on cross-sectional data rather time series data. But the study still has successfully found some new findings. Hope, these results will drive other researchers to do better in this exploration covering all aspects of this study. Further researches can be carried out to take into account a large number of respondents all over the textile sectors in the country and also comprising time-series data. The future researcher can also consider different performance measures and their impact on performance.

\section{CONCLUSION}

Bangladesh textile sector is going through a challenging period now. The high inflation rate, increased production cost, competition, labor unrest, lacking in research and development, countries situation is being the troublesome 
factors. In this study, the internal measurement techniques to increase the performance of the firm have been analyzed. The respondents of this study represent a wide variety in the production of textiles and follow different measures given by the mid-level managers. Hence, the variation is expected for a limited number of sample sizes, and the result may have some limitations due to publicly unavailability of data. From literature, the questionnaire is developed to support and cover the current position of the industries in their measurement and performance. The results show very significant influences of performance measures and performance with the manufacturing quality strategy. This study is a thoughtful-contribution to diversified performance measures, its types, joint, partly effect on, and interrelation with the performance. Findings of the study states quality strategy fit with actions to be approved by the top management for higher performance. Local textile companies can ensure better performance by evaluating various performance measures.

\section{REFERENCES}

Absar, M.M.N., Azim, M.T. and Akhter, S. (2010). Research on HRM Practices in Bangladesh: A Review of Literature and Directions for Future Studies. Management Development, 27(2 \& 3), 19-32.

Aveyard, H. (2010). Doing a Literature Review in Health and Social Care: A Practical Guide. In 2nd (Ed.). Berkshire, Great Britain: Open University Press.

Baumann-Pauly, D., Labowitz, S., \& Banerjee, N. (2015). Closing Fovernance Gaps in Bangladesh's Garment Industry-The Power and Limitations of Private Governance Schemes. Retrieved 2018, from

http:/ / papers.ssrn.com/sol3/papers.cfm?abstract_id=2577 $535 \&$ download $=$ yes

Bennett, M. and James, P. (1999). Sustainable Measures: Evaluation and Reporting of Environmental and Social Performance. Sheffield, UK: Greenleaf.

BGMEA. (n.d.). Retrieved 1 9, 2018, from http://www.bgmea.com.bd/member/memberlist

BGMEA. (n.d.). www.bgmea.com.bd. Retrieved 5 1, 2019

$B K M E A$. (n.d.). Retrieved 1 4, 2018, from http://www.bkmea.com/member

Casadesus-Masanell, R. and Ricart, J.E. (2010). From Strategy to Business Models and to Tactics. Long Range Planning, 195215.

Chandler, A. (1977). The Visible Hand-Managerial Revolution in American Business. Harvard University Press, Boston, MA., 417.

Chandler, A. D. (1962). Strategy and Structure. Cambridge, USA: MIT press.

Chow, C.W. and Van der Stede, W.A. (2006). The Use and Usefulness of Nonfinancial Performance Measures. Management Accounting Quarterly, 7(3), 1-8.

Chowdhury, M. F. (2011). Performance Management Practices in Organizations Operating in Bangladesh: A Deeper Examination. World Review of Business Research, 1(2), 153-167.
Farhana, F., and Amir, A. (2009). Lean Production Practice: the Differences and Similarities in Performance between the Companies of Bangladesh and other Countris of the World. Asian Journal of Business Management, 1(1), 32-36.

Fiksel, J. (1997). Practical Issues in Environmental Performance Evaluation. Tibor: T. and I. Feldman, Implementing ISO 14001.

Fiksel, J., McDaniel, J. and Mendenhall, C. (1999). Progress Towards Sustainability Principles, Process, and Best Practices. Greening of Industry Network Conference Best Practice Processings. 505 King Avenue, Columbus, Ohio: Battlele Memorial Institute, LIfe Cycle Management Group.

Fitzgerald, L., Johnston, R., Brignall, S., Silvestro, R., and Voss, C. (1992). Performance Measurement in Service Businesses (Management Accounting Handbook, Drury, C. (Ed) ed.). London: Butterworth Heinmann.

Habib, M. R. (2009). Backward Linkages in Readymade Garment Industry of Bangladesh: Appraisal and Policy Implications. Journal of Textile and Apparel Technology and Management, $6(2), 1-10$.

Hammer, M. and Champy, J. (1993). Re-engineering the Corporation: A manifesto for Business Revolution. London: Nicholas Brealey.

Haque, N. (2015). Implementing Industrial Energy Efficiency (IEE) in Bangladesh: Leassons Learned from the Textile and Garment Industry. International Journal of Environment, 5(1), 20-25.

Harper, J. (1984). Measuring Business Performance: A manager's Guide. Aldershot: Gower Publishing.

Hasan, J. (2013). The Competitiveness of Ready Made Garments Industry of Bangladesh in Post MFA Era: How Does the Industry Behave to Face the Competitive Challenge? British Journal of Economics, Management E Trade, 3(3), 296-306.

Hasan, K.M.F., Mia, M.S., Ashaduzzaman, Rahman, M.M., Ahmed Ullah, A.N.M. and Ullah, M.S. (2016). Role of Textile and Clothing Industries in the Growth and Development of Trade \& Business Strategies of Bangladesh in the Global Economy. Intematonal Journal of Textile Science, 5(3), 39-48.

IISD (1992) International Institute for Sustainable Development. Deloitte \& Touche. Business Council for Sustainable Development. Business strategy for sustainable development: leadership and accountability for the '90s. Winnipeg: International Institute for Sustainable Development.

Islam, M. M. (2015). HRM Practices in Small and Medium-sized Textile Industry of Bangladesh. ASA University Review, 9(2), $1-26$.

Ittner, C.C., and Larcker, D.F. (1995). Total Quality Management and the Choice of Information and Reward System. Journal of Accounting Research, 33 (Supplement), 1-34.

James, P. (1997). The Sustainability Cycle: A New Tool for Product Development and Design. Journal for Sustainable Produce Design.

Kaplan, R.S., and Atkinson, A.A. (1989). Advanced Management Accounting (2nd ed.). NJ: Prentice-Hall, Englewood Cliffs.

Kaplan, R.S., and Norton, D.P. (1992, January/February). The Balanced Scorecrd Measures That Drive Performance. 71-79. 
Lingle, J. H. and Schiemann, W.A. (1996). From Balanced Scorecrd to Strategy Gauge: is measurement worth it? Management Review, 56-62.

Lynch, R.L., and Cross, K.F. (1991). Measure Up-the Essential Guide to Measure Business Performance. Mandarin, London.

Manas, T. (1999). Making the Balanced Scorecard Approach Pay Off. American Compensation Association Journal, Second Quarter, 13-21.

Masum, M., \& Inaba, K. (2015). A A comparative input-output analysis of the textile-clothing industry in Bangladesh and some Asian countries. 10th RICA, Conference. Bangkok, Thailand.

Mintzberg, H. (1987). the strategy concept I: Five Ps for Strategy, General Strategic Theory. California Management Review, 1124.

Mintzberg, H. (2007). Tracking Strategy: Toward a General Theory of Strategy Formation. UK: Oxford University Press.

Moseley, G. B. (2009). Managing Health Care Business Strategy. LLC.: Jones and Barlett Publishers.

Mostafa, M. G. (2006). Challenges, Opportunities, and Threats of Textile Sector in Bangladesh: A Look into the Dacca Dyeing and Manufacturing Company Limited. Daffodil International University Journal of Business and Economics, 1(1), 46-59.

Neely, A. (1999). The performance measurement revolution: why now and what next? Internationsl Journal of Operations and Production Management, 19(2), 205-228.

Noor-E-Hasnin, and Ahsan, M. (2016). Employee Training and Operational Risks: The Case of RMG Sector in Bangladesh. World Journal of Social Sciences, 6(2), 71-81.

Porter, M. E. (1966). What is Strategy. Harvard Business Review, 60.

RSA. (1994). Tomorrow's Company: The Role of Business in Changing World, interim report. London: Royal Society of Arts, Manufacturers and Commerce.

Scholtes, P. R. (1993). Total Quality or Performance Appraisal: Choose One. National Productivity Review, 12(3), 439-363.

Shafiqul, I. M. (2014). Informal Labor Incentives and Firm Performance: A Case Study of RMG Industry in Bangladesh. International Business and Management, 8(2), 19-27.
Slack, N., Chambers, S., Harland, C., Harrison, A. and Johnston, R. (1995). Operations Management. London: Pitman.

Starcher, R. (1992). Mismatched Management Techniques. Quality Progress, 25(12), 49-52.

Taticchi, P., Cagnazzo, L., and Botarelli, M. (2008). Performance Measurement and Management (PMM) for SMEs: a literature review and a reference framework for PMM design. POMS 19th Annual Conference La Jolla. California, USA.

Teece, D. J. (2010). Business Models, Business Strategy and Innovation. Long Range Planning, 172-194.

Van der Stede, W.A., Chow, C.W. and Lin, T.W. (2006). Strategy, Choice of Performance Measures, and Performance. Behavioral Research in Accounting, 18, 185-205.

Zairi, M., and Letza, S. (1994). Performance Measurement: A Challenge for Total Quality and the Accounting Professions. Asia Pacific Journal of Quality Management, 3(2), 26-41.

$$
--0--
$$

\section{ACKNOWLEDGEMENT}

Special thanks goes to Md. Ismail Mollah, Principal, Textile Engineering College, Zorargonj, Chittagong; Priyantha Wijetunge (Sri-Lanka), Ex-ED, and Gertrudes Valdez, Technician Industrial Engineering, Intimate Apparels BD. Ltd., KEPZ, Chittagong for their cordial help in learning the real-life experiences in the production of the Textile Sectors. Final thanks go to "BUBT Research Centre" for their training on " $4^{\text {th }}$ Intensive Training Program on Applied Research Methodology" by Prof. Santi Narayan Ghosh and Prof. Dr. Syed Masud Husain. Without the help of our teachers it was quite impossible to do this study. Finally, authors are highly thankful to Md. Manjurul Alam, SEO, SIBL, Head Office. 


\section{APPENDIX}

Questionnaire on

\section{"Choice of Performance Measures and Performance of Textile Sector in Bangladesh"} Survey Section on Performance Measures

With respect to the current performance measurement system in place, please check all the measures that are used by upper management to gauge your department's performance.

(Please only check (or write in) those measures that are reported, analyzed, and discussed on a regular basis for the purpose of performance measurement and evaluation.)

1. FINANCIAL PERFORMANCE MEASURES FOR YOUR DEPARTMENT (Check all that apply.)

Cash Flow

Working capital

Cost base

Borrowing (e.g., loans or overdrafts)

Financing growth with changing needs

Profitability ratio (fall under margins and returns)

Gross profit margin

Operating expenses margin

Net profit margin

Return on capital employed (e.g., ROI)

Liquidity (ability to meet short term obligations)

Solvency (ability to meet long-term debt against assets and equity)

Efficiency

Other (please list):

2. Objective non-financial measures:

1. CUSTOMER-ORIENTED PERFORMANCE MEASURESFOR YOUR DEPARTMENT (Check all that apply.)

Assessment of Market share and position

Time to fill customer orders

Delivery performance (e.g., on-time delivery, percent of correct delivery)

Time to respond to customer problems

Flexibility /responsiveness (i.e., ability to vary product characteristics)

Customer satisfaction (e.g., results from customer surveys, number of customer complaints)

Customer acquisition (e.g., number of new customers, percent sales from new customers)

Customer retention/ loyalty (e.g., number of repeat customers)

Mystery shopping by someone pose as customer

Other (please list):

2. INTERNAL OPERATING PERFORMANCE MEASURESFOR YOUR DEPARTMENT (Check all that apply.)

Production volume

Labor productivity (e.g., hours used/hours available, overtime hours)

Machine productivity (e.g., hours running/hours available, downtime on equipment)

Material usage (e.g., material usage inefficiency, material waste)

Setup efficiency (e.g., setup time, number of setups)

Manufacturing cycle time (e.g., total process time)

Inventory (e.g., inventory turnover)

Product defects (e.g., number of errors, rework, scrap)

New product introductions (e.g., total number, percentage of sales from new products)

New product-design efficiency (e.g., time to develop new products, on-time schedule)

Working condition/environment

Other (please list):. 
3. EMPLOYEE-ORIENTED PERFORMANCE MEASURESFOR YOUR DEPARTMENT (Check all that apply.)

A. Innovation Performance Measures For your department (Check all that apply.)

Employee empowerment (e.g., number of suggestions submitted, \% of employees on improvement teams)

Modernization with the new skills or technology

Problem solving

Ability in making comparisons (individual or group)

The power of information technology

National and international awards;

Specific improvement initiatives

The changing nature of work

Other (please list):

B. LEARNING PERFORMANCE MEASURESFOR YOUR DEPARTMENT (Check all that apply.)

Employee training/education (e.g., number of hours or \% of employees' time allocated for training) Employee loyalty/turnover (e.g., years in job, years with firm, absenteeism)

Efficiency

Time of employee devotes

Safety (e.g., number of accidents, number of injuries)

Employee satisfaction (e.g., results of employee surveys, number of grievances filed)

Employee skills (e.g., level of education, level of experience)

Other (please list):

3. SUSTAINABILITY RELATED MEASURES FOR YOUR DEPARTMENT (Check all that apply.)

Address perspectives of resources consumption (e.g., energy, material, water, land, waste, cost, human capital, invest capital)

Concentrate on perceptions of value creation (e.g., performance, satisfaction, human health, information content, Business competency)

Economic, environment and social aspects included in evaluation of performance (triple bottom line considered)

Evaluation considering each stage of product life cycle (e.g., supply, manufacturing, use, disposition, recycle or reuse)

Leading indicators (e.g., process or material efficiency improvement)

Lagging indicators (e.g., measure of outcome or result)

Other (please list):

4. SUBJECTIVE PERFORMANCE MEASURES FOR YOUR DEPARTMENT (Check all that apply.)

The above categories dealt with the performance measures that are quantified and reported on a regular basis. However, performance evaluations by upper management also may include subjective assessments of various, not always clearly specified, aspects of performance. Which of the following factors do you believe upper management makes an assessment of when evaluating your performance? (Check all that apply.)

My long-term perspective on the business

My ability to effectively acquire new skills /knowledge

My willingness to share knowledge within the organization

My cooperation with other departments within the organization

My managerial skills

My loyalty toward the firm

Employee spirit/morale in my department

My ability to compare with other organizations in the same sector

My ability to focus on areas that drive business success.

My understanding over research competitors and market trends

Other (please list) 
5. PLEASE LIST KEY PERFORMANCE INDICATORS (KPIs) YOU FOLLOW TO UNDERSTAND THE OVERALL PERFORMANCE OF YOUR INDUSTRY (In chronological order)

a)

b)

c)

d)

e)

The above measures can be classified into three categories: (1) financial performance measures (from Section 1 above); (2) objective nonfinancial performance measures (Sections 1, 2, 3); (3) sustainability performance measures (Section 4); (4) subjective performance measures (Section 5), and 5. Key performance indicators used which are the terminologies we use in the questions that follow.

Online Archive: https://abc.us.org/ojs/index.php/abr/issue/archive 